\title{
ANALISIS PENGARUH INDEKS PEMBANGUNAN MANUSIA, PDRB PER KAPITA, DAN JUMLAH PENGANGGURAN TERHADAP JUMLAH PENDUDUK MISKIN DI PROVINSI JAMBI
}

\author{
Yunie Rahayu \\ STIE Muhammaadiyah Jambi
}

\begin{abstract}
Poverty is a problem faced by all countries in the world, especially the developing countries, such as Indonesia. Poverty is a complex issue that is affected by a variety of interrelated factors, such as people's income levels, unemployment, health, education, access to goods and services, geographic location, gender, and location the environment. The number of poor population in Central Java is relatively lebihtinggi compared to laindi province of Indonesia, that is occupying ranked second in the number of poor population the largest in Indonesia after East Java. This research aims to analyze how and how much the variable influences the human development index, GDP per capita, and the number of poor population against unemployment in Jambi province in the year 2016. Methods of analysis in this study using multiple linear regression analysis with the method of Ordinary Least Square (OLS) that use data between spaces (cross section) district/town in Jambi province year 2016 with the help of software Eviews 4.1. The results of this research indicate that the variable is the human development index (HDI) a negative and significant effect against the poor population in the province of Jambi, the per capita GDP is negative and significant effect against the number of poor population in The province of Jambi, the unemployment and the number of positive and significant effect against the poor population in the province of Jambi.
\end{abstract}

Keywords: population of the poor, the human development index (HDI), GDP per capita, and the number of Unemployed

\section{PENDAHULUAN}

Pembangunan adalah suatu proses perubahan menuju ke arah yang lebih baik dan terus menerus untuk mencapai tujuan yakni mewujudkan masyarakat Indonesia yang berkeadilan, berdaya saing, maju, dan sejahtera dalam wadah Negara Kesatuan Republik Indonesia. Pembangunan harus diarahkan sedemikian rupa sehingga setiap tahap semakin mendekati tujuan. Hidup layak merupakan hak asasi manusia yang diakui secara universal. Konstitusi Indonesia UUD’45, secara eksplisit mengakui hal itu dengan mengamanatkan bahwa tugas pokok pemerintah Republik Indonesia adalah "memajukan kesejahteraan umum, mencerdaskan kehidupan bangsa serta mewujudkan suatu keadilan sosial bagi seluruh rakyat Indonesia". Hal itu berarti, hidup bebas dari kemiskinan atau menikmati kehidupan yang layak merupakan hak asasi setiap warga negara adalah tugas pemerintah untuk menjamin terwujudnya hal itu. Pembangunan nasional pada dasarnya ialah meningkatkan kesejahteraan umum yang adil dan merata bagi seluruh rakyat Indonesia.

Oleh karena itu, salah satu indikator utama keberhasilan pembangunan nasional adalah laju penurunan jumlah penduduk miskin.Efektivitas dalam menurunkan jumlah penduduk miskin merupakan pertumbuhan utama dalam memilih strategi atau instrumen pembangunan.Hal ini berarti salah satu kriteria 
utama pemilihan sektor titik berat atau sektor andalan pembangunan nasional adalah efektivitas dalam penurunan jumlah penduduk miskin (Simatupang dan Saktyanu, 2003).

Kemiskinan merupakan masalah yang dihadapi oleh semua negara di dunia, terutama negara sedang berkembang. Kemiskinan merupakan masalah kompleks yang dipengaruhi oleh berbagai faktor yang saling berkaitan, antara lain tingkat pendapatan masyarakat, pengangguran, kesehatan, pendidikan, akses terhadap barang dan jasa, lokasi, geografis, gender, dan lokasi lingkungan. Kemiskinan tidak lagi dipahami hanya sebatas ketidakmampuan ekonomi, tetapi juga kegagalan memenuhi hak-hak dasar dan perbedaan perlakuan bagi seseorang atau sekelompok orang dalam menjalani kehidupan secara bermartabat. Hak-hak dasar yang diakui secara umum meliputi terpenuhinya kebutuhan pangan, kesehatan, pendidikan, pekerjaan, perumahan, air bersih, pertanahan, sumber daya alam, lingkungan hidup, rasa aman dari perlakuan atau ancaman tindak kekerasan, dan hak berpartisipasi dalam kehidupan sosial politik

Banyak dampak negatif yang disebabkan oleh kemiskinan, selain timbulnya banyak masalah- masalah sosial, kemiskinan juga dapat mempengaruhi pembangunan ekonomi suatu negara. Kemiskinan yang tinggi akan menyebabkan biaya yang harus dikeluarkan untuk melakukan pembangunan ekonomi menjadi lebih besar, sehingga secara tidak langsung akan menghambat pembangunan ekonomi. Kemiskinan merupakan penyakit yang muncul saat masyarakat selalu mempunyai kekurangan secara material maupun non material seperti $\mathrm{k}$ urang makan, kurang gizi, kurang pendidikan, kurang akses informasi, dan kekurangankekurangan lainnya yang menggambarkan kemiskinan. Faktor lainyang sangat nyata tentang kemiskinan terutama di kota-kota besar Indonesia, dapat dilihat dari banyaknya warga masyarakat yang kekurangan makan dan minum, tidak memiliki tempat tinggal yang layak, bahkan digusur dari pemukimannya, ribuan pekerja berunjuk rasa memprotes ancaman pemutusan hubungan kerja (PHK), sikap dan perlakuan sewenang-wenang terhadap tenaga kerja wanita di luar negeri. Kemudian ketidakadilan sosial ekonomi, selain oleh beragam alasan juga disebabkan oleh praktek korupsi, kolusi, dan nepotisme yang tidak sehat.

Kondisi kemiskinan di pemerintahan Provinsi Jambi tidak jauh berbeda dengan di pemerintahan pusat (problem nasional), yakni masih tingginya jumlah penduduk miskin jika di bandingkan dengan provinsi lain di sumatera. Sepanjang tahun 2013 sampai dengan tahun 2016, penduduk miskin di Provinsi Jambi mengalami kenaikan di tahun 2015 sebesar 0.47\%. Penyebab kemiskinan bermuara pada teori lingkaran kemiskinan (vicious circle of poverty) dari $\mathrm{N}$ urkse 1953. Adanya keterbelakangan, dan ketertinggalan SDM (yang tercermin oleh rendahnya IPM), ketidaksempurnaan pasar, dan kurangnya modal menyebabkan rendahnya produktifitas. Rendahnya produktifitas mengakibatkan rendahnya pendapatan yang mereka terima (yang tercermin oleh rendahnya PDRB per kapita). Rendahnya pendapatan akan berimplikasi pada rendahnya tabungan dan investasi. Rendahnya investasi berakibat pada rendahnya akumulasi modal sehingga proses penciptaan lapangan kerja rendah (tercemin oleh tingginya jumlah pengangguran). Rendahnya akumulasi modal disebabkan oleh keterbelakangan dan seterusnya (Kuncoro, 1997).

Kualitas sumber daya manusia juga dapat menjadi faktor penyebab terjadinya penduduk miskin.Kualitas sumber daya manusia dapat dilihat dari indeks kualitas hidup/indeks pembangunan manusia. Rendahnya Indeks 
Pembangunan Manusia (IPM) akan berakibat pada rendahnya produktivitas kerja dari penduduk. Produktivitas yang rendah berakibat pada rendahnya perolehan pendapatan.Sehingga dengan rendahnya pendapatan menyebabkan tingginya jumlah penduduk miskin. Salah satu indikator tingkat kesejahteraan penduduk suatu wilayah adalah angka PDRB per kapita.PDRB per kapita sering digunakan sebagai indikator pembangunan.Semakin tinggi PDRB per kapita suatu daerah, maka semakin besar pula potensi sumber penerimaan daerah tersebut dikarenakan semakin besar pendapatan masyarakat daerah tersebut (Thamrin, 2001).Hal ini berarti juga semakin tinggi PDRB per kapita semakin sejahtera penduduk suatu wilayah. Dengan kata lain jumlah penduduk miskin akan berkurang.

Selain faktor- faktor di atas, adapula indikator lain yang digunakan untuk mengukur jumlah penduduk miskin pada Kabupaten/Kota di Provinsi Jambi yaitu seberapa besar jumlah pengangguran yang ada pada Kabupaten/Kota di Jambi tersebut. Pengangguran bisa disebabkan oleh bertambahnya angkatan kerja baru yang terjadi tiap tahunnya, sementara itu penyerapan tenaga kerja tidak bertambah. Selain itu adanya industri yang bangkrut sehingga harus merumahkan tenaga kerjanya. Hal ini berarti, semakin tinggi jumlah pengangguran maka akan meningkatkan jumlah penduduk miskin.

\section{Telaah Pustaka}

\section{Definisi dan Ukuran Kemiskinan}

Kemiskinan merupakan masalah yang dihadapi oleh seluruh negara, terutama negara sedang berkembang. Pengertian kemiskinan secara luas adalah keterbatasan yang disandang seseorang, keluarga, komunitas, atau bahkan negara yang menyebabkan ketidaknyamanan dalam kehidupan, terancamnya penegakan hukum dan keadilan serta hilangnya generasi serta hilangnya generasi bangsa. Kemiskinan multi dimensional, artinya karena kebutuhan manusia itu bermacammacam, maka kemiskinan pun memiliki banyak aspek primer yang berupa miskin akan aset, organisasi sosial politik, pengetahuan, dan keterampilan serta aspek sekunder yang berupa miskin akan jaringan sosial, sumber-sumber keuangan, dan informasi. Dimensi- dimensi kemiskinan tersebut termanifestasikan dalam bentuk kekurangan gizi,air, perumahan yang sehat, perawatan kesehatan yang kurang baik, dan tingkat pendidikan yang rendah. Selain itu,dimensi-dimensi kemiskinan saling berkaitan baik secara langsung maupun tidak langsung. Hal ini berarti kemajuan atau kemunduran pada salah satu aspek dapat mempengaruhi kemajuan atau kemunduran aspek lainnya. Dan aspek lain dari kemiskinan ini adalah bahwa yang miskin itu manusianya baik secara individual maupun kolektif (Arshad,1999).

Ukuran kemiskinan menurut Nurkse dalam Arshad (1999): pertama, Kemiskinan Absolut: Seseorang termasuk golongan miskin absolut apabila hasil pendapatannya berada di bawah garis kemiskinan dan tidak cukup untuk menentukan kebutuhan dasar hidupnya; kedua, Kemiskinan Relatif: Seseorang termasuk golongan miskin relatif apabila telah dapat memenuhi kebutuhan dasar hidupnya, tetapi masih jauh lebih rendah dibandingkan dengan keadaan masyarakat sekitarnya. Kebutuhan dasar dapat dibagi menjadi dua golongan yaitu kebutuhan dasar yang diperlukan sekali untuk mempertahankan hidupnya dan kebutuhan lain yang lebih tinggi. United Nation Research Institute for Social Development (UNRISD) menggolongkan kebutuhan dasar manusia atas tiga kelompok yaitu: pertama, Kebutuhan fisik primer yang terdiri dari kebutuhan 
gizi, perumahan, dan kesehatan; kedua, Kebutuhan kultural yang terdiri dari pendidikan, waktu luang (leisure), dan rekreasi serta ketenangan hidup; dan ketiga, Kelebihan pendapatan untuk mencapai kebutuhan lain yang lebih tinggi.

Kebutuhan dasar tidak hanya meliputi kebutuhan keluarga, tetapi juga meliputi kebutuhan fasilitaslingkungan kehidupan manusia,seperti yang dikemukakan oleh Internasional Labor Organization (ILO, 1976) sebagai berikut: pertama, kebutuhan yang meliputi tuntutan minimum tertentu dari suatu keluarga konsumsi pribadi seperti makanan yang cukup, tempat tinggal, pakaian, juga peralatan dan perlengkapan rumah tangga yang dilaksanakan. Kedua, kebutuhan meliputi pelayanan sosial yang diberikan oleh dan untuk masyarakat seperti air minum yang bersih, pendidikan, dan kultural (Arshad,1999).

\section{Penyebab Kemiskinan}

Sharp (1996) mengidentifikasi penyebab kemiskinan dari sisi ekonomi: pertama, Secara mikro,kemiskinan muncul karena adanya ketidaksamaan pola kepemilikan sumberdaya yang menimbulkan distribusi pendapatan yang timpang; kedua, Kemiskinan muncul akibat perbedaan dalam kualitas sumberdaya manusia; ketiga, Kemiskinan muncul akibat perbedaan akses dalam modal.

\section{Teori Lingkaran Kemiskinan}

Ketiga penyebab kemiskinan diatas bermuara pada teori lingkaran kemiskinan (vicious circle of poverty).Adanya keterbelakangan, ketidaksempurnaan pasar, dan kurangnya modal menyebabkan rendahnya produktifitas.Rendahnya produktifitas mengakibatkan rendahnya pendapatan yang mereka terima. Rendahnya pendapatan akanberimplikasi pada rendahnya tabungan dan investasi, baik invetasi manusia maupun investasi kapital. Rendahnya investasi berakibat pada keterbelakangan dan seterusnya.Logika berpikir ini dikemukakan oleh Ragnar Nurkse 1953, yang mengatakan " a poor country is a poor because it is poor” (negara miskin itu miskin karena diamiskinan.

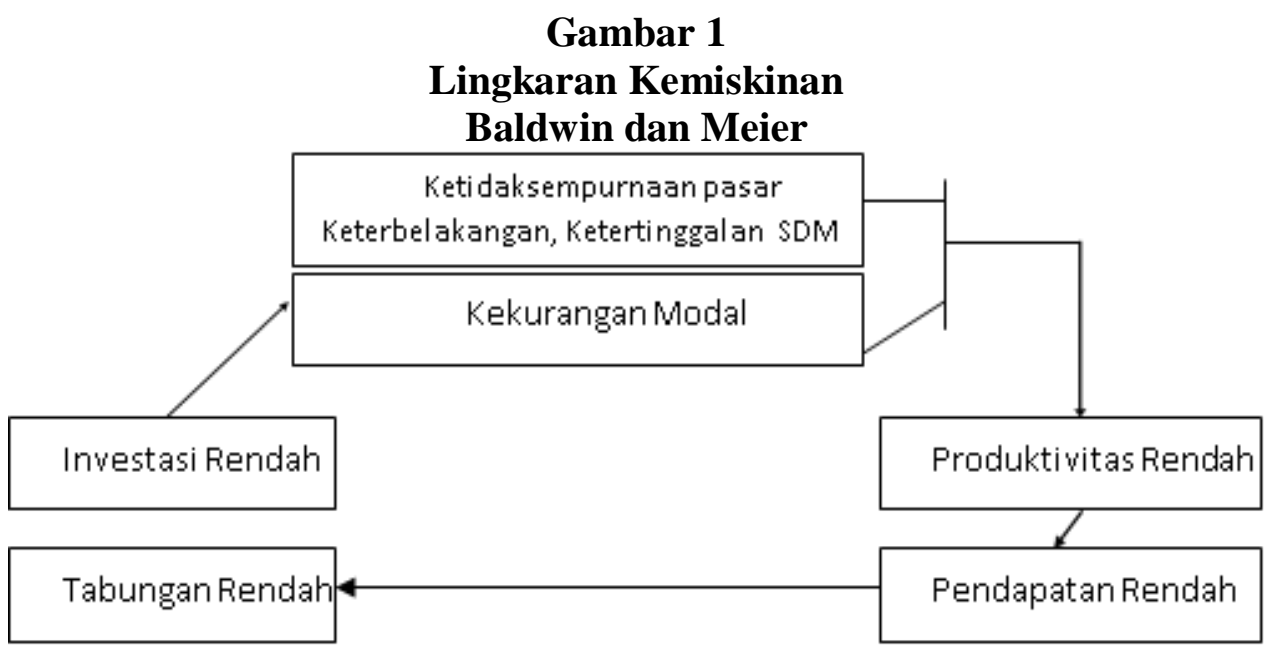

Sumber: Kuncoro, 1997

Menurut Nurkse ada dua lingkaran perangkap kemiskinan, yaitu dari segi penawaran (supply) dimana tingkat pendapatan masyarakat yang rendah yang diakibatkan oleh tingkat produktivitas yang rendah menyebabkan kemampuan masyarakat untuk menabung rendah. Kemampuan untuk menabung rendah, 
menyebabkan tingkat pembentukan modal yang rendah, tingkat pembentukan modal (investasi) yang rendah menyebabkan kekurangan modal, dan dengan demikian tingkat produktivitasnya juga rendah dan seterusnya.Dari segi permintaan (demand), di negara-negara yang miskin perangsang untuk menanamkan modal adalah sangat rendah, karena luas pasar untuk berbagai jenis barang adanya terbatas, hal ini disebabkan oleh karena pendapatan masyarakat sangat rendah. Pendapatan masyarakat sangat rendah karena tingkat produktivitas yang rendah, sebagai wujud dari tingkatan pembentukan modal yang terbatas di masalalu.Pembentukan modal yang terbatas disebabkan kekurangan perangsang untuk menanamkan modal dan seterusnya.

\section{Indeks Pembangunan Manusia}

Ukuran pembangunan yang digunakan selama ini, yaitu PDB-dalam konteks nasional dan PDRB-dalam konteks regional, hanyamampu memotret pembangunan ekonomi saja.Untuk itu dibutuhkan suatu indikator yang lebih komprehensif, yang mampu menangkap tidak saja perkembangan ekonomi akantetapi juga perkembangan aspek sosial dan kesejahteraan manusia. Penghitungan IPM sebagai indikator pembangunan manusiamemiliki tujuan penting, diantaranya: pertama, Membangun indikator yang mengukur dimensi dasar pembangunan manusia dan perluasan kebebasan memilih; kedua, Memanfaatkan sejumlah indikator untuk menjaga ukuran tersebut sederhana; ketiga, Membentuk satu indeks komposit dari pada menggunakan sejumlah indeks dasar; dan keempat, Menciptakan suatu ukuran yang mencakup aspek sosial dan ekonomi.

Indeks tersebut merupakan indeks dasa $r$ yang tersusun dari dimensi berikut ini: pertama, umur panjang dan kehidupan yang sehat, dengan indikator angka harapan hidup; kedua, Pengetahuan, yang diukur dengan angka melek huruf dan kombinasi dari angka partisipasi sekolah untuk tingkat dasar, menengah dan tinggi; ketiga, Standar hidup yang layak, dengan indikator PDRB per kapita dalam bentuk PurchasingPower Parity (PPP).

Konsep Pembangunan Manusia yang dikembangkan oleh Perserikatan Bangsa-Bangsa (PBB), menetapkan peringkat kinerja pembangunan manusia pada skala $0,0-100,0$ dengan katagori sebagai berikut:

- $\quad$ Tinggi : IPM lebih dari 80,0

- $\quad$ Menengah Atas : IPM antara 66,0 -79,9

- Menengah Bawah : IPM antara 50,0 -65,9

- $\quad$ Rendah : IPM kurang dari 50,0

\section{PDRB per kapita}

PDRB per kapita dapat dijadikan sebagai salah satu indikator guna melihat keberhasilan pembangunan perekonomian di suatu wilayah.PDRB adalah nilai bersih barang dan jasa-jasa akhir yang dihasilkan oleh berbagai kegiatan ekonomi di suatu daerah dalam periode (Sasana, 2006). PDRB dapat menggambarkan kemampuan suatu daerah mengelola sumber daya alam yang dimilikinya.Oleh karena itu besaran PDRB yang dihasilkan oleh masing- masing daerah sangat bergantung kepada potensi sumber daya alam dan faktor produksi daerah tersebut.Adanya keterbatasan dalam penyediaan faktor- faktor tersebut menyebabkan besaran PDRB bervariasi antar daerah. Sedangkan PDRB per kapita dapat dihitung dari PDRB harga kosntan dibagi dengan jumlah penduduk pada 
suatu wilayah.

Menurut BPS (2008) angka PDRB dapat diperoleh melalui tiga pendekatan, yaitu: pertama, pendekatan produksi: jumlah nilai barang dan jasa akhir yang dihasilkan oleh berbagai unit produksi yang berada di suatu wilayah/provinsi dalam jangka waktu tertentu; kedua, pendekatan pendapatan: balas jasa yang diterima oleh faktor-faktor yang ikut serta dalam proses produksi di suatu wilayah dalam waktu tertentu; ketiga, pendekatan pengeluaran: penjumlahan semua komponen permintaan akhir.

\section{Pengangguran}

Pengangguran adalah seseorang yang sudah digolongkan dalam angkatan kerja yang secara aktif sedang mencari pekerjaan pada suatu tingkat upah tertentu, tetapi tidak dapat memperoleh pekerjaan yang diinginkannya (Sukirno, 2000). Menurut Sukirno (2000) pengangguran biasanya dibedakan atas 3 jenis berdasarkan keadaan yang menyebabkannya, antara lain: pertama, Pengangguran friksional, yaitu pengangguran yang disebabkan oleh tindakan seseorang pekerja untuk meninggalkan kerjanya dan mencari kerja yang lebih baik atau sesuai dengan keinginannya; kedua, Pengangguran struktural, yaitu pengangguran yang disebabkan oleh adanya perubahan struktur dalam perekonomian; dan ketiga, Pengangguran konjungtur, yaitu pengangguran yang disebabkan oleh kelebihan pengangguran alamiah dan berlaku sebagai akibat pengurangan dalam permintaan agregat.

Menurut Edwards dalam Arsyad (1999), untuk mengelompokkan masingmasing pengangguran perlu diperhatikan dimensi-dimensi sebagai berikut: pertama, waktu (banyak diantara mereka yang bekerja ingin bekerja lebih lama, misal jam kerjanya per hari, per minggu, atau per bulan); kedua, Intensitas pekerjaan (yang berkaitan dengan kesehatan dan gizi makanan); dan ketiga, Produktivitas (kurangnya produktivitas seringkali disebabkan oleh kurangnya sumberdaya-sumberdaya komplementer untuk melakukan pekerjaan). Berdasarkan hal- hal diatas Edwards memberikan bentuk-bentuk pengangguran adalah: pertama, Pengangguran terbuka (open unemployment), adalah mereka yang mampu dan seringkali sangat ingin bekerja tetapi tidak tersedia pekerjaan yang cocok untuk mereka; kedua, Setengah pengangguran (under unemployment), adalah mereka yang secara nominal bekerja penuh namun produktivitasnya rendah sehingga pengurangan dalam jam kerjanya tidak mempunyai arti atas produksi secara keseluruhan; ketiga, Tenaga kerja yang lemah (impaired), adalah mereka yang mungkin bekerja penuh tetapi intensitasnya lemah karena kurang gizi atau penyakitan; dan keempat, Tenaga kerja yang tidak produktif, adalah mereka yang mampu bekerja secara produktif tetapi tidak bisa menghasilkan sesuatu yang baik.

Salah satu faktor penting yang menentukan kemakmuran masyarakat adalah tingkat pendapatan. Pendapatan masyarakat mencapai maksimum apabila tingkat penggunaan tenaga kerja penuh dapat terwujudkan, sehingga apabila tidak bekerja atau menganggur maka akan mengurangi pendapatan dan hal ini akan mengurangi tingkat kemakmuran yang mereka capai dan dapat menimbulkan buruknya kesejahteraan masyarakat (Sukirno,2004).

\section{METODE}

Variabel terikat dalam penelitian ini adalah jumlah penduduk miskin di Propinsi Jambi tahun 2016, sedangkan variabel bebasnya adalah Indeks 
Pembangunan Manusia (IPM), PDRB per kapita, dan Jumlah Pengangguran. Definisi operasional adalah suatu definisi yang diberikan kepada suatu variabel atau konstruk dengan caramemberikan arti atau menspesifikasikan kegiatan, ataupun memberikan suatu operasional yang diperlukan untuk mengukur konstruk atau variabel tersebut (M. Nasir, 1998). Sebagai panduan untuk melakukan penelitian dan dalam rangka pengujian hipotesis yang diajukan, maka perlu dikemukakan definisi variabel yang digunakan.

Definisi operasional dari masing- masing variabel adalah sebagai berikut:

a. Jumlah PendudukMiskin

Penduduk yang pendapatan per kapitanya kurang dari sepertiga rata-rata pendapatan perkapita nasional, maka termasuk dalam kategori miskin.Dalam penelitian ini data yang digunakan adalah data jumlah penduduk miskin pada Kabupaten/Kota diProvinsi Jambi dalam satuan jiwa.

b. Indeks PembangunanManusia

Indeks Pembangunan Manusia (IPM) merupakan ukuran capaian pembangunan manusiaberbasis sejumlah komponen dasar kualitas hidup.Data IPM yang digunakan adalah data IPM pada Kabupaten/Kota di Provinsi Jambi tahun 2016.

c. PDRB perkapita

PDRB per kapita adalah Produk Domestik Regional Bruto (PDRB) dibagi dengan jumlah penduduk di setiap wilayah Kabupaten/Kota Jambi.Data PDRB per kapita yang digunakan adalah PDRB per kapita tahun 2016 atas harga konstan tahun 2000. Variabel ini memiliki satuanrupiah.

d. JumlahPengangguran

Jumlah pengangguran adalah jumlah orang yang masuk dalam angkatan kerja yang sedang mencari pekaerjaan dan belum mendapatkannya.Data jumlah pengangguran yang digunakan adalah jumlah pengangguran menurut Kabupaten/Kota di Provinsi Jambi tahun 2016.Variabel ini memiliki satuan jiwa.

\section{Jenis dan Sumber Data}

Jenis data yang digunakan adalah data kuantitatif. Data kuantitatif terdiri dari data jumlah penduduk miskin, data indeks pembangunan manusia, data PDRB per kapita, dan data jumlah pengangguran.Data yang digunakan sebagai latar belakang berupa tahun periode 2013-2016. Sumber data yang digunakan dalam penelitian ini adalah data sekunder, yaitu data yang diperoleh dalam bentuk yang sudah jadi atau sudah dikumpulkan dari sumber lain dan diperoleh dari pihak lain seperti buku-buku literatur, catatan-catatan atau sumber yang berhubungan dengan masalah yang diteliti. Adapun data yang diambil adalah data seluruh Kabupaten/Kota di Provinsi Jambi sebanyak 9 Kabupaten dan 2 Kota.Tahun yang dipilih adalah tahun2013 sampai dengan tahun 2016.

\section{Metode Pengumpulan Data}

Data yang digunakan untuk mencapai tujuan dalam penelitian ini sepenuhnya melalui data sekunder. Data yang diperoleh merupakan data-data dari literatur yang berkaitan baik berupa, dokumen, artikel, catatan-catatan, maupun arsip.Data yang diperoleh kemudian disusun dan diolah sesuai dengan kepentingan dan tujuan penelitian. Untuk tujuan penelitian ini data yang dibutuhkan adalah data seluruh Kabupaten/Kota di Provinsi Jambi yang diperoleh 
dari Badan Pusat Statistik (BPS) jambi.Meliputi data jumlah penduduk miskin, data Indeks Pembangunan Manusia, data PDRB per kapita, dan data jumlah pengangguran.

\section{Metode Analisis}

Metode analisis data yang digunakan dalam penelitian ini adalah menggunakan analisis regresi linear berganda dengan menggunakan metode Ordinary Least Square (OLS) di Provinsi Jambi tahun 2013 - 2016.

\section{Analisis Regresi}

Analisis regresi adalah studi ketergantungan dari variabel dependen pada satu atau lebih variabel independen (Gujarati,1999). Dalam analisis ini dilakukan dengan bantuan program SPSS dengan tujuan untuk melihat pengaruh variabelvariabel independen terhadap variabel dependennya. Metode yang digunakan dalam penelitian ini adalah menggunakan regresi berganda dengan metode kuadrat terkecil sederhana Ordinary Least Squares (OLS). Metode ini diyakini mempunyai sifat-sifat yang ideal dan dapat diunggulkan yaitu secara teknis sangat kuat, mudah dalam perhitungan dan penarikan interpretasinya. Model yang digunakan dalam penelitian ini dijabarkan dalam fungsi sebagai berikut:

$\mathrm{POV}_{\mathrm{t}}=\beta_{0} . \mathrm{IPM}_{\mathrm{t}}^{\beta 1}$. PDRBK ${ }_{\mathrm{t}}^{\beta 2} \cdot \mathrm{U}_{\mathrm{t}}$

Keterangan: $\mathrm{POV}_{\mathrm{t}}=$ Jumlah penduduk miskin Kab/Kota di Provinsi Jambi; PMM $_{t}=$ Indeks Pembangunan Manusia Kab/Kota di Provinsi; PDRBK $_{t}=$ PDRBperkapitaKab/Kota di Provinsi Jambi; $U_{t}=$ Jumlah pengangguran

Kab/Kota di Provinsi Jambi

\section{HASIL}

\section{Analisis Regresi}

Model regresi yang digunakan adalah metode analisis regresi linier berganda (Ordinary Least Squares Regression Analysis). Untuk menganalisis faktor yang mempengaruhi jumlah penduduk miskin di Provinsi Jambi, Peneliti menggunakan model data cross section tersebut untuk mengetahui pengaruh variabel Indeks Pembangunan Manusia (IPM), PDRB per kapita (PDRBK), dan Jumlah Pengangguran (U) terhadap Jumlah Penduduk Miskin (POV) di Provinsi Jambi.

Metode Ordinary Least Square (OLS) menggunakan jumlah penduduk miskin sebagai variabel dependen yang dipengaruhi oleh variabel independen yaitu Indeks Pembangunan Manusia, PDRB per kapita, dan Jumlah Pengangguran dengan menggunakan data cross section tahun 2013-2016, maka diperoleh nilai koefisien regresi yang dapat dirangkum dengan persamaan fungsional sebagai berikut:

$\mathrm{POV}=15,946-0,09 \mathrm{IPM}-0,413 \mathrm{PDRBK}+2,75 \mathrm{U}$

Pada persamaan tersebut, variabel independen yang berpengaruh signifikan secara statistik terhadap jumlah penduduk miskin adalah variabel Indeks Pembangunan Manusia, PDRB per kapita, dan Jumlah Pengangguran.

Interpretasi dari hasil regresi persamaan diatas adalah sebagai berikut:

\section{Indeks Pembangunan Manusia}

Hasil regresi persamaan menunjukkan slope koefisien dari Indeks Pembangunan Manusia (IPM) menunjukkan angka -0,09 yang berarti bahwa 
kenaikan 1 persen angka Indeks Pembangunan Manusia akan menurunkan jumlah penduduk miskin sebesar 0,09 persen. Pada persamaan tersebut Indeks Pembangunan Manusia (IPM) hubungannya negatif dan signifikan pada $\alpha=5 \%$.

\section{PDRB per kapita}

Hasil regresi persamaan menunjukkan slope koefisien dari PDRB per kapita menunjukkan angka -0.413 yang berarti bahwa kenaikan 1 persen angka PDRB per kapita akan menurunkan jumlah penduduk miskin sebesar 0.413 persen. Pada persamaan tersebut PDRB per kapita hubungannya negatif dan signifikan pada $\alpha=5 \%$.

\section{Jumlah Pengangguran}

Hasil regresi persamaan menunjukkan slope koefisien dari Unemployment/ Jumlah Pengangguran (U) menunjukkan angka 0.yang berarti bahwa kenaikan 1 persen angka Jumlah Pengangguran akan meningkatkan jumlah penduduk miskin sebesar2,75 persen. Pada persamaan tersebut Unemployment/ Jumlah Pengangguran(U) hubungannya positif dan signifikan pada $\alpha=5 \%$.

\section{SIMPULAN} berikut:

Berdasarkan hasil penelitian, maka dapat ditarik kesimpulan sebagai

a. Model regresi pengaruh Indeks Pembangunan Manusia (IPM), PDRB per kapita, dan jumlah pengangguran di Provinsi Jambidi tahun 2013-2016 cukup layak digunakan karena telah memenuhi dan melewati uji asumsi klasik, yaitu uji normalitas, uji multikolinearitas, uji heteroskedastisitas dan ujiautokorelasi.

b. Hasil uji koefisien determinasi $\left(\mathrm{R}^{2}\right)$ Indeks Pembangunan Manusia (IPM), PDRB per kapita, dan jumlah pengangguran di Provinsi Jambi di tahun 20132016 menunjukkan bahwa besarnya nilai $R^{2}$ tidak begitu tinggi yaitu 0,143 artinya variabel independen (Indeks Pembangunan Manusia, PDRB per kapita, dan Jumlah Penggangguran) dapat menerangkan variabilitas sebesar 14,3\% dari variabel dependen (Jumlah PendudukMiskin).

c. Indeks Pembangunan Manusia (IPM) berpengaruh negatif dan signifikan secara statistik terhadap jumlah penduduk miskin tahun 2013-2016. Hal ini mengindikasikan bahwa peningkatan Indeks Pembangunan Manusia akanberakibat pada meningkatnya produktivitas kerja dari penduduk, sehingga akan meningkatkan perolehan pendapatan. Hal ini berarti juga semak in tinggi perolehan pendapatan akan menyebabkan penurunan jumlah penduduk miskin.Hasil regresi ini ditunjang dengan data bahwa adanya kecenderungan kenaikan Indeks Pembangunan Manusia di Jambi tahun 20132016 pada sebagian besar Kabupaten/Kota di Provinsi Jambi diiringi dengan penurunan jumlah penduduk miskin dibeberapa Kabupaten/Kota di Jambi.

d. PDRB per kapita berpengaruh negatif dan signifikan secara statistik terhadap jumlah penduduk miskin tahun 2013-2016. Hal ini mengindikasikan bahwa semakin besarnya PDRB per kapita maka semakin sejahtera penduduk suatu wilayah. Dengan kata lain semakin besar PDRB per kapita, jumlah penduduk miskin akan berkurang.

e. Jumlah pengangguran berpengaruh positif dan signifikan secara statistik terhadap jumlah penduduk miskin tahun 2013-2016. Hal ini berarti, 
berkurangnya jumlah pengangguran akan berakibat pada berkurangnya jumlah penduduk miskin di suatu wilayah. Hasil regresi ini ditunjang dengan data bahwa berkurangnya jumlah pengangguran di Jambi tahun 2013-2016 pada sebagian besar Kabupaten/Kota di Jambi diiringi dengan penurunan jumlah penduduk miskin dibeberapa Kabupaten/Kota di Provinsi Jambi

\section{DAFTAR PUSTAKA}

Apriliyah S. Napitupulu. 2007. Pengaruh Indikator Komposit Indeks Pembangunan Manusia Terhadap Penurunan Jumlah Penduduk Miskin di Sumatera Utara. http://www.google.com.Diakses tanggal 5 Oktober 2010.

Badan Pusat Statistik. 2013-2016. Indeks Pembangunan Manusia Propinsi Jambi dan Kabupaten/Kota Jambi. Jambi 2013-2016. Jambi Dalam Angka Jambi.

Deny Tisna Amijaya. 2008. Pengaruh Ketidakmerataan Distribusi Pendapatan Pertumbuhan Ekonomi, dan Pengangguran terhdap Tingkat Kemiskinan di Indonesia tahun 2003-2004. Skripsi, IESP Fakultas Ekonomi UNDIPSemarang.

Dian Octaviani. 2001. Inflasi, Pengangguran, dan Kemiskinan di Indonesia: Analisis Indeks Forrester Greer dan Horbecke. Media Ekonomi.Vol 7 No.2, 100-118.

Hermanto S., Dwi W. 2006. Dampak Pertumbuhan Ekonomi terhadap Penurunan Penduduk Miskin di Indonesia: Proses Pemerataan dan Pemiskinan. Direktur Kajian Ekonomi, Institusi Pertanian. Bogor.

Mankiw, G. 2007. Macro Economic. Edisi keempat. Jakarta: Erlangga.

Rima Prihartanti. 2008. Analisis kemiskinan,Pertumbuhan Ekonomi, dan Ketimpangan Distribusi Pendapatan: Studi Kasus antar Kabupaten/Kota di Propinsi Jawa Tengah. Skripsi, IESP Fakultas Ekonomi UNDIP. Semarang.

Soleh, A. 2017. Masalah Ketenagakerjaan dan Pengangguran di Indonesia. Cano Ekonomos, 6(2), 83-92.

Soleh, A. 2016. Analisis Pertumbuhan Ekonomi Indonesia. Jurnal Development, 4(2), 18-26.

Irmanelly, I., \& Soleh, A. 2013. Analisis Sektor Unggulan dan Hubungannya dengan Ketenagakerjaan dan Kemiskinan di Provinsi Jambi. Jurnal Development, 1(1), 15-43.

Todaro, Michael P. 2000. Pembangunan Ekonomi di Dunia Ketiga. Edisi Ketujuh. (Terj). Haris Munandar. Jakarta: Penerbit Erlangga.

Tulus H. Tambunan. 2001. Perekonomian Indonesia. Jakarta: Penerbit Ghalia Indonesia.

Wing Wahyu Winarno. 2008. Analisis Ekonometrika dan Statistika dengan EViews. Yogyakarta: Penerbit UPP STIM YKPN. 